\title{
Koordinasi Kewenangan pada Pengusahaan Panas Bumi untuk Keperluan Tenaga Listrik
}

\author{
Canggih Prabowo*
}

\begin{abstract}
Abstrak
Penyediaan energi terbarukan melalui pemanfaatan tidak langsung panas bumi merupakan tanggung jawab bersama antara pemerintah pusat dengan pemerintah daerah. Hal ini menimbulkan kewenangan sebagaimana diamanatkan Undang-Undang Nomor 30 Tahun 2007 tentang Energi dan Undang-Undang Nomor 30 tahun 2009 tentang Ketenagalistrikan. Seiring tuntutan penyediaan tenaga listrik mengalami peningkatan, beberapa kendala berupa koordinasi dan perizinan penggunaan kawasan hutan turut terjadi. Hal ini turut menjadi alasan perubahan Undang-Undang Nomor 32 Tahun 2004 tentang Pemerintahan Daerah dan Undang-Undang Nomor 27 Tahun 2003 tentang Panas Bumi. Namun demikian, perubahan tersebut menimbulkan kerancuan berkenaan implementasi otonomi daerah menurut Pasal 18 Undang-Undang Dasar Negara Republik Indonesia Tahun 1945. Perselisihan koordinasi kewenangan antara badan dan/atau pejabat pemerintahan, dalam hal ini pemerintah kabupaten dengan Kementerian ESDM, juga telah muncul dan telah menjadi perkara yang diajukan ke Mahkamah Konsitusi.
\end{abstract}

Kata kunci: kehutanan, ketenagalistrikan, pembagian kewenangan, koordinasi, panas bumi.

\section{Authorities Coordination on Geothermal Operations for Electricity Use}

\begin{abstract}
The provision of renewable energy through the use of indirect geothermal energy is a shared responsibility of the central government with local government authorities, as mandated in Law Number 30 Year 2007 on Energy and Law Number 30 of 2009 on Electricity. As the demand of electricity supply is increasing, some obstacles in the form of coordination and licensing the use of the forest area are also on the rise. On that basis, Law Number 32 Year 2004 on Regional Government and Law Number 27 Year 2003 on Geothermal are amended. Nevertheless, these changes create confusion in respect to the implementation of regional autonomy in accordance with Article 18 of the Constitution of the Republic of Indonesia Year 1945. Furthermore, a dispute on authorities coordination between governmental body and/or government officials, in this case between local government and the Ministry of Energy and Mineral Resources, has arisen and has also been brought to the Constitutional Court.
\end{abstract}

Keywords: forestry, electricity, distribution of authorities, coordination, geothermal.

PADJADJARAN Jurnal IImu Hukum Volume 3 Nomor 2 Tahun 2016 [ISSN 2460-1543] [e-ISSN 2442-9325]

* Mahasiswa Magister Hukum Universitas Parahyangan, canggihprabowo@gmail.com, S.H. (Universitas Padjadjaran) 


\section{A. Pendahuluan}

Seiring pertambahan jumlah penduduk, pengembangan wilayah, dan perkembangan aktivitas ekonomi di sektor industri dan rumah tangga, kebutuhan akan energi tenaga listrik terus mengalami peningkatan. Sejalan dengan hasil studi PT Perusahaan Listrik Negara (PLN), Pulau Jawa diperkirakan akan mengalami krisis listrik pada tahun 2018 akibat permintaan listrik meningkat tiap tahunnya dengan pertumbuhan rata-rata sekitar $9 \%$ per tahun. ${ }^{1}$ Dari pertumbuhan rata-rata tersebut, penggunaan energi fosil untuk keperluan listrik masih mendominasi, sebagaimana ditandai dengan besaran pemanfaatan batu bara dan gas bumi yaitu masing-masing sebesar 50\% (26 Gigawatt-GW) dan 23\% (12 GW) diikuti kemudian oleh minyak bumi sebesar $14 \%(7,5 \mathrm{GW}) .^{2}$ Penggunaan jenis pembangkit tersebut untuk memenuhi kebutuhan listrik pada wilayah terpenci di luar Jawa dan Sumatera terbilang tinggi, padahal di sisi lain masih terdapat 2.519 desa yang belum memperoleh jaringan listrik di Indonesia. ${ }^{3}$

Tidak dapat dipungkiri bahwa ketersediaan energi yang memadai dan berkesinambungan merupakan faktor penting sebagai penopang produktivitas dan daya saing industri serta meningkatkan kesejahteraan masyarakat. ${ }^{4}$ Pada saat ini, fungsi energi menjadi lebih strategis, yakni tidak hanya sebagai sumber penerimaan negara tetapi juga dapat berfungsi sebagai katalisator pertumbuhan ekonomi dan bahkan sebagai aspek penting yang menentukan ketahanan nasional suatu negara. ${ }^{5}$ Pada saat yang bersamaan, sektor energi Indonesia masih mengalami kesulitan untuk memenuhi pasokan dan distribusi listrik karena kapasitas penyediaan pembangkit tenaga listrik tidak secepat pertumbuhan ekonomi. ${ }^{6}$ Sebagai contoh di tahun 2006 terjadi krisis pasokan listrik hingga terjadi pemadaman bergilir. ${ }^{7}$

Menanggapi penyediaan listrik yang semakin mendesak, di tahun 2010 pemerintah mulai serius melakukan diversifikasi energi sebagai upaya untuk

1 Kementerian Energi dan Sumber Daya Mineral (ESDM), "Rencana Strategis Kementerian Energi dan Sumber Daya Mineral Tahun 2010-2014", 2010, hlm. 7.

2 Agus Sugiyono, (et.al.) (eds), “Outlook Energi Indonesia 2016: Pengembangan Energi Untuk Mendukung Industri Hijau", Jakarta: Pusat Teknologi Sumber Daya Energi dan Industri Kimia dan Badan Pengkajian dan Penerapan Teknologi (BPPT), 2016, hlm. 16.

3 Direktoral Jenderal Ketenagalistrikan Kementerian Energi dan Sumber Daya Mineral (Dirjen Ketenagalistrikan ESDM), "Pemerintah Dorong Swasta Kembangkan Listrik Perdesaan”,

http://www.djk.esdm.go.id/index.php/detail-berita?ide=4210, diakses 26 Maret 2015.

4 Ibid. hlm. 145.

5 Direktorat Sumber Daya Energi, Mineral dan Pertambangan, “Keselarasan Kebijakan Energi Nasional Dengan Rencana Umum Energi Nasional dan Rencana Umum Energi Daerah", Policy Paper, Badan Perencanaan Pembangunan Nasional, 2012, hlm. 1.

6 Tuti Ermawati dan Siwage Dharma Negara, Pengembangan Industri Energi Alternatif: Studi Kasus Energi Panas Bumi di Indonesia, Jakarta: Lembaga Ilmu Pengetahuan Indonesia Press, 2014, hlm.145.

$7 \quad$ ESDM, “Tanpa Pertumbuhan Pembangkit, 2018 Pulau Jawa Krisis Listrik”, http://www2.esdm.go.id/berita/39listrik/6745-tanpa-pertumbuhan-pembangkit-2018-pulau-jawa-krisis-listrik.html, diakses 26 Maret 2015. 
penganekaragaman penggunaan energi non-minyak bumi. Diversifikasi energi dilakukan melalui pengurangan penggunaan batu bara, gas bumi, dan minyak dengan menerapkan energi terbarukan sebagai bahan bakar utama pembangkit listrik dalam proyek listrik 10.000 Mwe tahap kedua berdasarkan Peraturan Presiden Nomor 4 Tahun 2010 sebagaimana diubah melalui Peraturan Presiden Nomor 194 Tahun 2014 tentang Perubahan Kedua atas Peraturan Presiden Nomor 4 Tahun 2010 tentang Penugasan Kepada PT Perusahaan Listrik Negara (Persero) Untuk Melakukan Percepatan Pembangunan Pembangkit Tenaga Listrik yang Menggunakan Energi Terbarukan, Batu Bara dan Sumber Daya Mineral (PP 4/2010).

Upaya tersebut kemudian ditindaklanjuti dengan penerbitan Peraturan Menteri Energi Sumber Daya Mineral Nomor 2 Tahun 2010 sebagaimana telah diubah beberapa kali terakhir dengan Peraturan Menteri Energi Sumber Daya Mineral Nomor 32 Tahun 2014 tentang Perubahan Ketiga atas Peraturan Menteri Energi dan Sumber Daya Mineral Nomor 15 Tahun 2010 tentang Daftar Proyek-Proyek Percepatan Pembangunan Pembangkit Tenaga Listrik yang Menggunakan Energi Terbarukan, Batubara dan Gas Serta Transmisi Terkait (Permen ESDM 32/2014).

Merujuk isi dan lampiran III Permen ESDM 32/2014, khususnya di Provinsi Jawa Barat, terdapat daftar proyek pembangkit tenaga listrik yang menggunakan energi terbarukan dan dilaksanakan melalui kerjasama pengembang listrik swasta,

C Tabel 1: Pengusahaan Panas Bumi di Kawasan Hutan Konservasi, Hutan Lindung dan Hutan Produksi di Provinsi Jawa Barat

\begin{tabular}{|c|c|c|c|c|c|}
\hline No & $\begin{array}{c}\text { Nama Proyek } \\
\text { Pembangkit }\end{array}$ & $\begin{array}{l}\text { Wilayah Kerja } \\
\text { Panas Bumi }\end{array}$ & $\begin{array}{c}\text { Kategori Fungsi } \\
\text { Hutan }\end{array}$ & $\begin{array}{c}\text { Sumber Daya } \\
\text { (Mwe) }\end{array}$ & Pengembang \\
\hline 1. & $\begin{array}{l}\text { PLTP Tangkuban } \\
\text { Perahu I }\end{array}$ & $\begin{array}{l}\text { Kabupaten Subang, } \\
\text { Kabupaten } \\
\text { Bandung, dan } \\
\text { Kabupaten } \\
\text { Purwakarta }\end{array}$ & $\begin{array}{l}\text { Kawasan Hutan } \\
\text { Lindung dan } \\
\text { Kawasan Hutan } \\
\text { Produksi }\end{array}$ & 110 Mwe & $\begin{array}{l}\text { PT. Wahana } \\
\text { Sambadha Sakti }\end{array}$ \\
\hline 2. & PLTP Cibuni & $\begin{array}{l}\text { Ciwidey, Kabupaten } \\
\text { Bandung }\end{array}$ & $\begin{array}{l}\text { Kawasan Hutan } \\
\text { Lindung }\end{array}$ & 10 Mwe & $\begin{array}{l}\text { Koperasi Jasa } \\
\text { Keahlian/KJK } \\
\text { Teknosa }\end{array}$ \\
\hline 3. & $\begin{array}{l}\text { PLTP Karaha } \\
\text { Bodas }\end{array}$ & $\begin{array}{l}\text { Kabupaten } \\
\text { Tasikmalaya dan } \\
\text { Kabupaten Garut }\end{array}$ & $\begin{array}{l}\text { Kawasan Hutan } \\
\text { Lindung }\end{array}$ & 200 Mwe & $\begin{array}{l}\text { PT Pertamina } \\
\text { Geothermal } \\
\text { Energy }\end{array}$ \\
\hline 4. & PLTP Patuha & Kabupaten Bandung & $\begin{array}{l}\text { Kawasan Hutan } \\
\text { Lindung }\end{array}$ & 220 Mwe & $\begin{array}{l}\text { PT Geodipa } \\
\text { Energy }\end{array}$ \\
\hline 5. & PLTP Tampomas & $\begin{array}{l}\text { Kabupaten } \\
\text { Sumedang dan } \\
\text { Kabupaten Subang }\end{array}$ & $\begin{array}{l}\text { Kawasan Hutan } \\
\text { Lindung }\end{array}$ & 55 Mwe & $\begin{array}{l}\text { PT Wijaya Karya } \\
\text { Jabar Power }\end{array}$ \\
\hline 6. & $\begin{array}{l}\text { PLTP Tangkuban } \\
\text { Perahu II }\end{array}$ & $\begin{array}{l}\text { Kabupaten Subang, } \\
\text { Kabupaten } \\
\text { Bandung, dan } \\
\text { Kabupaten } \\
\text { Purwakarta }\end{array}$ & $\begin{array}{l}\text { Kawasan Hutan } \\
\text { Lindung dan } \\
\text { Kawasan Hutan } \\
\text { Produksi }\end{array}$ & 60 Mwe & $\begin{array}{l}\text { PT Tangkuban } \\
\text { Perahu } \\
\text { Geothermal } \\
\text { Power }\end{array}$ \\
\hline
\end{tabular}




\begin{tabular}{|c|c|c|c|c|c|}
\hline 7. & $\begin{array}{l}\text { PLTP Wayang } \\
\text { Windu Unit } 3 \text { dan } \\
4\end{array}$ & Kabupaten Bandung & $\begin{array}{l}\text { Kawasan Hutan } \\
\text { Lindung }\end{array}$ & 460 Mwe & $\begin{array}{l}\text { Star Energy } \\
\text { Geothermal Ltd }\end{array}$ \\
\hline 8. & $\begin{array}{l}\text { PLTP Kamojang } 5 \\
\text { dan } 6\end{array}$ & $\begin{array}{l}\text { Kabupaten Garut } \\
\text { dan Kabupaten } \\
\text { Bandung }\end{array}$ & $\begin{array}{l}\text { Kawasan Hutan } \\
\text { Konservasi }\end{array}$ & 300 Mwe & $\begin{array}{l}\text { PT Pertamina } \\
\text { Geothermal } \\
\text { Energy }\end{array}$ \\
\hline 9. & $\begin{array}{l}\text { PLTP Cisolok- } \\
\text { Sukarame }\end{array}$ & $\begin{array}{l}\text { Kabupaten } \\
\text { Sukabumi }\end{array}$ & $\begin{array}{l}\text { Kawasan Hutan } \\
\text { Konservasi } \\
\text { Taman Nasional } \\
\text { Gunung } \\
\text { Halimun Salak } \\
\text { (3.800 hektar) }\end{array}$ & 45 Mwe & $\begin{array}{l}\text { Jabar Rekind } \\
\text { Geothermal }\end{array}$ \\
\hline 10. & $\begin{array}{l}\text { PLTP Gunung } \\
\text { Ciremai }\end{array}$ & $\begin{array}{l}\text { Kabupaten } \\
\text { Kuningan dan } \\
\text { Kabupaten } \\
\text { Majalengka }\end{array}$ & $\begin{array}{l}\text { Kawasan Hutan } \\
\text { Konservasi } \\
\text { Taman Nasional } \\
\text { Gunung Ciremai } \\
\text { ( } 24.330 \text { hektar) }\end{array}$ & 150 Mwe & - \\
\hline
\end{tabular}

Ket: Tabel diolah dari berbagai sumber

Dari tabel di atas terlihat kecenderungan bahwa tuntutan penyediaan energi terbarukan panas bumi untuk keperluan tenaga listrik akan diiringi dengan tuntutan penggunaan atau pemanfaatan kawasan hutan untuk kepentingan pembangunan peranan sektor kehutanan. Kemudian kawasan hutan konservasi yang secara khusus merupakan penyangga kehidupan akan mengalami perluasan cara pandang terhadap fungsi hutan, yakni diantaranya: ${ }^{8}$

(1) Fungsi ekonomi:

Hutan adalah sumber pendapatan negara yang dilakukan oleh badan usaha maupun masyarakat lokal dalam penyediaan dan kegiatan pengambilan kayu serta bahan baku kayu dan non kayu untuk berbagai kepentingan;

(2) Fungsi sosial:

Hutan memiliki nilai yang sangat tinggi sebagai arena penyeimbang antara dunia realitas dengan budaya kosmos bagi sebagian besar masyarakat Indonesia dalam sebuah sistem pengelolaan sumber daya hutan yang adil, lestari dan berkelanjutan; dan

(3) Fungsi ekologi:

Hutan menjadi penjaga stabilitas iklim mikro dan global, konservasi sumber daya air, sumber genetik dan habitat bagi keanekaragaman hayati.

Kedua kecenderungan tuntutan tersebut di satu sisi menimbulkan tanggung jawab dan kewenangan sebagaimana termuat dalam Undang-Undang Nomor 32 Tahun 2004 tentang Pemerintahan Daerah (UU Pemda 2004), yaitu:

$8 \quad H e r m a n$ Hidayat (et.al.), Politik Ekologi: Pengelolaan Taman Nasional Era Otda, , Jakarta: Lembaga IImu Pengetahuan Indonesia dan Yayasan Pustaka Obor Indonesia, 2011, hlm. 197. 


\begin{abstract}
Pasal 13 ayat (1):
Urusan wajib yang menjadi kewenangan pemerintahan daerah provinsi merupakan urusan dalam skala provinsi yang meliputi: $h$. Pelayanan bidang ketenagalistrikan lintas kabupaten/kota. Pasal 14 ayat (1):

Urusan wajib yang menjadi kewenangan pemerintahan daerah untuk kabupaten/kota merupakan urusan yang berskala kabupaten/kota meliputi:

p. urusan wajib lainnya yang diamanatkan oleh peraturan perundangundangan.
\end{abstract}

Berkenaan huruf $\mathrm{p}$ di atas, terkait dengan sektor energi dan sumber daya mineral berdasarkan Pasal 20 ayat (4) dan Pasal 21 ayat (2) Undang-Undang Nomor 30 Tahun 2007 tentang Energi (UU Energi) sebagai payung regulasi energi menyebutkan ketentuan yang sama yakni: "Penyediaan energi baru dan terbarukan wajib ditingkatkan oleh pemerintah dan pemerintah daerah sesuai kewenangannya."

Ketentuan ini terkait pula dengan kewenangan dan tanggung jawab penyediaan tenaga listrik selanjutnya ditegaskan dalam Undang-Undang Nomor 30 Tahun 2009 tentang Ketenagalistrikan (UU Ketenagalistrikan) yang menyebutkan:

Pasal 3 ayat (1):

Penyediaan tenaga listrik dikuasai oleh negara yang penyelenggaraannya dilakukan oleh pemerintah dan pemerintah daerah berlandaskan prinsip otonomi daerah.

Pasal 5 ayat (3):

Kewenangan pemerintah kabupaten/kota di bidang ketenagalistrikan meliputi:

d. kewenangan pemerintah kabupaten/kota di bidang ketenagalistrikan salah satunya adalah penetapan izin operasi yang fasilitas instalasinya dalam kabupaten/kota.

Ketentuan tersebut selaras dengan Pasal 10 ayat (7) Undang-Undang Nomor 27 Tahun 2003 tentang Panas Bumi (UU Panas Bumi 2003) yang menerangkan:

"Pemanfaatan Tidak Langsung untuk tenaga listrik adalah kegiatan usaha pemanfaatan energi Panas Bumi untuk pembangkit tenaga listrik, baik untuk kepentingan umum maupun untuk kepentingan sendiri dilakukan sesuai dengan ketentuan peraturan perundangundangan yang berlaku di bidang ketenagalistrikan."

Sedangkan di sisi lain, penggunaan kawasan hutan untuk kepentingan pembangunan terkait pengusahaan panas bumi meliputi: (a) eksplorasi; (b) studi 
kelayakan; dan (c) eksploitasi dengan merujuk tabel di atas. Sementara itu, dalam Pasal 38 ayat (1) Undang-Undang Nomor 41 Tahun 1999 sebagaimana telah diubah dengan Undang-Undang Nomor 19 Tahun 2004 tentang Kehutanan (UU Kehutanan) disebutkan bahwa penggunaan kawasan hutan untuk kepentingan pembangunan di luar kegiatan kehutanan hanya dapat dilakukan di dalam kawasan hutan produksi dan kawasan hutan lindung. Pasal 38 ayat (2) kemudian mengatur bahwa penggunaan kawasan hutan tersebut dapat dilakukan tanpa mengubah fungsi pokok kawasan hutan.

Pasal 38 ayat (3) mengatur bahwa penggunaan kawasan hutan untuk kepentingan pertambangan dilakukan melalui pemberian izin pinjam pakai oleh menteri dengan mempertimbangkan batasan luas dan jangka waktu tertentu serta kelestarian lingkungan. Pasal 38 ayat (4) kemudian melarang adanya penambangan dengan pola pertambangan terbuka di kawasan hutan lindung, sementara Pasal 38 ayat (5) mengatur bahwa pemberian izin pinjam pakai sebagaimana dimaksudkan pada ayat (3) yang berdampak penting, memiliki cakupan yang luas, serta bernilai strategis dilakukan oleh menteri atas persetujuan Dewan Perwakilan Rakyat (DPR). Selain itu, Pasal 39 turut mengatur bahwa pelaksanaan ketentuan Pasal 38 tersebut diatur lebih lanjut dalam peraturan pemerintah.

Permasalahan yang timbul dari ketentuan normatif di atas adalah masih luasnya penafsiran atas ketentuan tersebut, yaitu:

(1) Koordinasi, tanggung jawab dan kewenangan antara pemerintah kabupaten dengan Kementerian Energi dan Sumber Daya Alam Mineral (Kementerian ESDM) dan Kementerian Kehutanan dan Lingkungan Hidup (Kemenhut LH);

(2) Implementasi penggunaan kawasan hutan untuk kepentingan pembangunan. Kedua permasalahan ini semakin menguat melalui Nota Kesepahaman antara Kementerian Energi dan Sumber Daya Alam Mineral dengan Kementerian Kehutanan Nomor 7662/05/MEM.S/2001 dan Nomor NK.16/Menhut-II/2011 tentang Percepatan Perizinan Pengusahaan Panas Bumi pada Kawasan Hutan Produksi, Kawasan Hutan Lindung, dan Kawasan Hutan Konservasi (Nota Kesepahaman)

Dari uraian di atas, maka permasalahan yang dibahas dalam tulisan ini adalah sebagai berikut: pertama, apakah pembagian urusan pemerintahan berkenaan kewenangan dan tanggung jawab pengusahaan panas bumi telah sesuai; kedua, apabila muncul perselisihan koordinasi kewenangan antara badan dan/atau pejabat pemerintahan, dalam hal ini pemerintah kabupatan dengan Kementerian ESDM, maka proses serta pilihan forum penyelesaian sengketa mana yang dipergunakan.

\section{B. Pembagian Urusan Pemerintahan}

\section{Panas Bumi}

Pengusahaan panas bumi di Indonesia sebenarnya bukanlah hal baru karena telah 
mulai dikembangkan sejak tahun 1976 dan diawali oleh pembentukan Koordinasi Energi Nasional (Bakoren) setingkat dengan departemen yang bertanggung jawab memformulasikan kebijakan energi serta mengkoordinasikan implementasi kebijakan ini. Bakoren untuk pertama kalinya mengeluarkan Kebijaksanaan Umum Bidang Energi (KUBE) pada tahun 1981. Kemudian KUBE 1981 selanjutnya direvisi pada tahun 1987 dan 1991. ${ }^{9}$ Merujuk kebijakan tersebut, pemerintah ketika itu menerbitkan beberapa keputusan presiden, diantaranya yaitu:

a) Keputusan Presiden Nomor 22 Tahun 1981 tentang Pemberian Kuasa Eksplorasi dan Ekspolitasi Panas Bumi Untuk Pembangkit Energi/Listrik Kepada Pertamina di Indonesia; dan

b) Keputusan Presiden Nomor 45 Tahun 1991 tentang Perubahan Keputusan Presiden Nomor 22 Tahun 1981 tentang Pemberian Kuasa Eksplorasi dan Ekspolitasi Panas Bumi Untuk Pembangkit Energi/Listrik Kepada Pertamina di Indonesia.

Berdasarkan dua keputusan presiden tersebut, diketahui pemerintah daerah tidak memiliki kewenangan karena pemerintah memberikan kewenangan pengusahaan panas bumi yang luas kepada Perusahaan Minyak dan Gas Bumi Negara (PT Pertamina). Namun demikian, di tahun 1998 pengusahaan panas bumi belum optimal karena KUBE 1998 dalam hal pemanfaatan diversifikasi energi menetapkan batu bara sebagai bahan bakar utama pembangkit listrik. Walaupun demikian, di tahun tersebut Indonesia mengalami krisis moneter, namun pemerintah tetap mengusahakan energi panas bumi kendati dengan prioritas yang berbeda dengan memberikan tuntutan penyelengaraan kepada pemerintah daerah berdasarkan Undang-Undang 22 Tahun 1999 tentang Pemerintahan Daerah (UU Pemda 1999) melalui Keputusan Presiden Nomor 76 Tahun 2000 tentang Pengusahaan Sumber Daya Panas Bumi untuk Pembangkit Tenaga Listrik (Keppres 76/2000).

Berdasarkan Keppres 76/2000 ini, monopoli PT Pertamina dicabut dan pemerintah daerah diberi kewenangan dalam hal perizinan sebagaimana dinyatakan dalam Pasal 5 yang berbunyi:

"Kepala Daerah sesuai dengan kewenangannya masing-masing memberikan Izin Pengusahaan sumber daya panas bumi pembangkitan tenaga listrik untuk kepentingan sendiri di wilayah usahanya dalam jangka waktu paling lama 90 (sembilan puluh) hari kalender setelah permohonan izin diterima secara lengkap."

Mencermati jenis produk hukum berupa keputusan presiden, menurut beberapa kalangan belum memberikan kepastian hukum dalam pengusahaan panas bumi bagi para pemangku kepentingan, terutama mengantisipasi realisasi penye-

9 Direktorat Sumber Daya Energi, Mineral dan Pertambangan, Op.cit., hlm. 8. 
lenggaraan otonomi daerah dan tugas pembantuan serta perimbangan keuangan pusat dan daerah.

Pada tahun 2003, pemerintah mengeluarkan Peraturan Presiden Nomor 5 Tahun 2006 tentang Kebijakan Energi Nasional/KEN (Perpres 5/2006) dan Peraturan Pemerintah Nomor 70 Tahun 2009 tentang Kebijakan Pengembangan Energi Terbarukan serta Konservasi Energi (PP 70/2009). Kedua peraturan presiden tersebut memperbaharui KUBE 1998, yaitu intensifikasi; diversifikasi; dan konservasi, dengan menambah instrumen legislasi dan kelembagaan berupa Dewan Energi Nasional (DEN) sebagai pengganti Bakoren.

Kebijakan ini selanjutnya menjadi acuan utama dalam penyusunan Rancangan Undang-Undang tentang Panas Bumi (RUU Panas Bumi) dan Rancangan UndangUndang tentang Energi (RUU Energi). Dalam program legislasi nasional, keberadaan RUU Energi diharapkan sebagai payung hukum, koordinasi, dan implementasi dari seluruh undang-undang di bidang energi seperti minyak dan gas bumi, ketenagalistrikan, serta panas bumi. Kemudian pada 22 Oktober 2003, pemerintah mengesahkan UU Panas Bumi 2003 lebih awal dibandingkan dengan UU Energi yang disahkan pada 10 Agustus 2007, meski terkesan tumpang tindih dikarenakan beberapa pasal dalam UU Energi mengamanatkan penyusunan rencana umum energi nasional (RUEN) dan rencana umum energi daerah (RUED) berdasarkan KEN yang dapat dikatakan memberikan solusi terhadap harapan sebagaimana disinggung sebelumnya menyatakan:

Pasal 11 ayat (2):

Kebijakan energi nasional ditetapkan oleh Pemerintah dengan persetujuan Dewan Perwakilan Rakyat.

Pasal 12 ayat (2):

Dewan Energi Nasional bertugas:

a. merancang dan merumuskan kebijakan energi nasional untuk ditetapkan oleh Pemerintah dengan persetujuan DPR sebagaimana dimaksud dalam Pasal 1.1

Pasal 17 ayat (1):

Pemerintah menyusun rancangan umum energi nasional berdasarkan kebijakan energi nasional.

Pasal 18 ayat (1):

Pemerintah daerah menyusun rencana umum energi daerah dengan mengacu pada rencana umum energi nasional sebagaimana dimaksud dalam Pasal 17 ayat (1)

Namun demikian, apabila merujuk bagian penjelasan, maka Pasal 11 ayat (2) UU Energi telah menyatakan cukup jelas. Meskipun ketentuan di atas tidak menyebutkan secara tegas jenis peraturan perundang-undangan, dengan mencermati frasa "...ditetapkan oleh Pemerintah dengan persetujuan Dewan Perwakilan 
Rakyat" maka berdasarkan Pasal 8 ayat (2) Undang-Undang Nomor 12 Tahun 2011 tentang Pembentukan Peraturan Perundang-Undangan (UU P-3U) ditegaskan bahwa: "Peraturan Perundang-undangan sebagaimana dimaksud pada ayat (1) diakui keberadaannya dan mempunyai kekuatan hukum mengikat sepanjang diperintahkan oleh Peraturan Perundang-undangan yang lebih tinggi atau dibentuk berdasarkan kewenangan."

Dari ketentuan tersebut, terdapat 2 (dua) syarat agar peraturan-peraturan sebagaimana dimaksud dalam Pasal 8 ayat (1) UU P-3U memiliki kekuatan mengikat sebagai peraturan perundang-undangan, yaitu:

1. Diperintahkan oleh peraturan perundang-undangan yang lebih tinggi; atau

2. Dibentuk berdasarkan kewenangan.

Menurut A. Hamid S. Attamimi, apabila ditinjau dari dasar kewenangan pembentukannya, maka dikenal 2 (dua) macam peraturan perundang-undangan, yaitu:

1. Kewenangan delegasi dalam pembentukan peraturan perundang-undangan: Pemindahan/penyerahan kewenangan untuk membentuk peraturan dari pemegang kewenangan asal yang mem-berdelegasi (delegans) kepada yang menerima delegasi (delegataris) dengan tanggung jawab pelaksanaan kewenangan tersebut pada delegataris sendiri, sedangkan tanggung jawab delegani terbatas sekali. ${ }^{10}$

2. Kewenangan atribusi dalam pembentukan peraturan perundang-undangan: Perundang-undangan diartikan penciptaan wewenang (baru) oleh konstitusi /grondwet atau oleh pembentuk undang-undang (wetgever) yang diberikan kepada suatu organ negara, baik yang sudah ada maupun yang dibentuk baru untukitu. ${ }^{11}$

Beranjak dari penjelasan tersebut, Pasal 17 ayat (1) UU Energi mengatur bahwa tidak semua persetujuan DPR harus berbentuk undang-undang. Walau demikian, ketika persetujuan dalam bentuk produk hukum maka secara formil harus menjadi undang-undang yang bersinggungan dengan pemerintah daerah sebagaimana undang-undang Anggaran Pendapatan Belanja Negara (APBN) menimbulkan undang-undang baru. Selain itu merujuk risalah rapat pembahasan RUU Energi sejak 2005 hingga 2007, maka maksud Pasal 17 ayat (1) UU Energi sama sekali tidak disinggung. Selain itu, Perpres 5/2006 juga kemudian dicabut dan dinyatakan tidak berlaku melalui Peraturan Pemerintah Nomor 79 Tahun 2014 tentang Kebijakan Energi Nasional (PP 79/2014).

10 A. Hamid S. Attamimi, "Peranan Keputusan Presiden Republik Indonesia Dalam Penyelenggaraan Pemerintahan Negara: Suatu Studi Analisis Mengenai Keputusan Presiden Yang Berfungsi Pengaturan Dalam Kurun Waktu Pelita I - Pelita VI", Disertasi, Jakarta: Fakultas Pasca Sarjana Universitas Indonesia, 1990, hlm. 347.

$11 \quad$ Ibid, hlm. 352. 
Dalam kaitannya dengan hal tersebut, Tumiran selaku anggota DEN dari unsur akademisi menyatakan bahwa berdasarkan Pasal 17 ayat (1) UU Energi maka idealnya KEN dituangkan dalam sebuah produk hukum berbentuk peraturan pemerintah. ${ }^{12} \mathrm{Hal}$ ini karena KEN merupakan sebuah kebijakan yang sangat strategis serta dengan pertimbangan waktu, produk hukum melalui undang-undang akan lama untuk itu dibentuk, maka untuk aturan turunan UU Energi dapat berupa peraturan pemerintah maupun peraturan presiden.

Dapat dikatakan bahwa pembentukan produk hukum sebagaimana diamanatkan dalam ketentuan tersebut menimbulkan kerancuan atau multitafsir mengenai KEN. Hal ini dikarenakan KEN sebagai materi yang perlu diatur dengan perkembangan atau kebutuhan hukum harus terlebih dahulu disusun oleh DEN, baru selanjutnya diserahkan kepada pemerintah. Selanjutnya, pemerintah meminta persetujuan DPR sehingga tidak memberikan suatu kepastian hukum dikarenakan belum selaras dengan asas pembentukkan peraturan perundangundangan yang baik.

Di samping itu, berdasarkan Putusan Mahkamah Konstitusi Nomor 31/PUUIV/2006 dalam perkara permohonan Pengujian Pasal 62 ayat (2) Undang-Undang Republik Indonesia Nomor 32 Tahun 2002 tentang Penyiaran terhadap UndangUndang Dasar Negara Republik Indonesia Tahun 1945 (UUD 1945) telah dijelaskan bahwa:

"Peraturan Pemerintah sebagaimana dimaksud dalam ayat (1) harus ditetapkan paling lambat 60 hari setelah selesai disusun oleh KPI bersama Pemerintah. Selanjutnya Mahkamah Konstitusi memutuskan:

Ketentuan mengenai Peraturan Pemerintah disusun oleh Pemerintah dalam hal ini Presiden sebagai penjabaran dari suatu undang-undang sebagai wewenang sepenuhnya dari pemerintah."13

Kemudian dalam perkembangannya, segala produk hukum terkait KEN akan turut mempengaruhi capaian pengusahaan panas bumi di kawasan hutan dalam konteks penyelengaraan otonomi daerah dan tugas pembantuan.

\section{Kehutanan}

Pengusahaan panas bumi di Indonesia dapat dikatakan masih akan bertumpu di wilayah Provinsi Jawa Barat untuk pembangkit skala besar sebagaimana digambarkan dalam tabel di atas. Provinsi Jawa Barat merupakan wilayah yang paling awal mengembangkan energi tersebut. Hal ini diimbangi dengan luas wilayah

12 Hukum Online, "Membedah Logika Hukum Peraturan Pemerintah Kebijakan Energi",

http://www.hukumonline.com/berita/baca/lt5301fa9d4242f/membedah-logika-hukum-pp-kebijakanenergi, diakses 17 Februari 2014.

13 Putusan Mahkamah Konstitusi No. 31/PUU-IV/2006, putusan diucapkan dalam sidang Pleno Mahkamah Konstitusi yang terbuka untuk umum pada hari Selasa, 25 Juli 2006, hlm. 136. 
sebesar 35.378 hektar dengan total luas hutan di Jawa Barat berdasarkan Surat Keputusan Menteri Kehutanan Nomor 195/Kpts-II/2003 seluas 816.603 hektar, sehingga 22,01\% dari luas wilayah Provinsi Jawa Barat merupakan kawasan hutan. Sesuai dengan peruntukkannya, luas hutan di Jawa Barat terbagi sebagai berikut: ${ }^{14}$

a) Hutan Konservasi, dikelola oleh: (1) Balai Besar Konservasi Sumber Daya Alam Jawa Barat dan Banten; (2) Balai Besar Taman Nasional Gunung Gede Pangrango; (3) Balai Taman Nasional Gunung Halimun Salak; (4) Balai Taman Nasional Gunung Ciremai seluas 132.180 hektar;

b) Hutan Produksi, dikelola oleh Perusahaan Umum Kehutanan Negara Jawa Barat Banten seluas 202.965 hektar;

c) Hutan Produksi Terbatas, dikelola oleh Perusahaan Umum Kehutanan Negara Jawa Barat Banten seluas 190.152 hektar; dan

d) Hutan Lindung, dikelola oleh Perusahaan Umum Kehutanan Negara Jawa Barat Banten seluas 291.306 hektar.

Merujuk pada pengelolaan beberapa fungsi kawasan hutan di Provinsi Jawa Barat, khususnya Taman Nasional Gunung Ciremai, maka untuk kepentingan pembangunan berkenaan pengusahaan panas bumi belum dapat dilaksanakan dikarenakan terkendala beberapa hal, antara lain sebagai berikut:

1) Regulasi dan Perizinan Penggunaan Kawasan Hutan Kegiatan panas bumi dikategorikan sebagai pertambangan dengan izin usaha melalui izin usaha pertambangan panas bumi dan membatasi bahwa penggunaan lahan kawasan hutan hanya dilakukan pada hutan produksi dan hutan lindung berdasarkan Pasal 38 ayat (1) UU Kehutanan melalui izin pinjam pakai kawasan hutan. Sedangkan potensi panas bumi di kawasan hutan konservasi sebesar $11 \%$ pada prinsipnya tidak dapat dilakukan dikarenakan kategori kegiatan tersebut dapat mengubah keutuhan zona inti taman nasional, sebagaimana diatur dalam Pasal 33 Undang-Undang Nomor 5 Tahun 1990 tentang Konservasi Sumber Daya Alam dan Ekosistem (UU Konservasi SDA) serta dalam Pasal 35 ayat (1) Peraturan Pemerintah Nomor 26 Tahun 2011 tentang Pengelolaan Kawasan Suaka Alam dan Kawasan Pelestarian Alam (PP 26/2011);

2) Kewenangan Urusan Pemerintahan Bidang Kehutanan Perizinan pinjam pakai kawasan hutan diberikan oleh Menteri Kehutanan berdasarkan permohonan mengacu surat rekomendasi gubernur bagi perizinan yang berkaitan dengan pinjam pakai kawasan hutan yang diterbitkan oleh bupati/walikota dan pemerintah. Sedangkan bupati/walikota menerbitkan rekomendasi bagi perizinan yang berkaitan dengan pinjam pakai kawasan hutan yang diterbitkan oleh gubernur berdasarkan Peraturan Pemerintah Nomor 24

14 Hermawan, "Lestarikan Hutan dan Lingkungan",

http://www.dishut.jabarprov.go.id/index.php?mod=detilSorotan\& idMenuKiri=345\&idSorotan=93, diakses 09 Desember 2016. 
Tahun 2010 tentang Penggunaan Kawasan Hutan dan Peraturan Menteri Kehutanan Nomor: P.43/Menhut-II/2008 tentang Pedoman Pinjam Pakai Kawasan Hutan;

3) Kewenangan Urusan Pemerintahan Bidang Energi

Perizinan untuk pemanfaatan tidak langsung dibagi antara pusat dan daerah, yakni pertama, pemerintah pusat berwenang menerbitkan melalui Kementerian ESDM apabila potensi panas bumi berada pada wilayah lintas provinsi. Kedua, pemerintah provinsi berwenang menerbitkan, apabila potensi panas bumi berada di wilayah lintas kabupaten/kota, sedangkan pemerintah kabupaten/kota berwenang menerbitkan apabila potensi panas bumi berada di kabupaten/kota;

4) Lemahnya Koordinasi Kewenangan antar Pemangku Kepentingan

a) Koordinasi kewenangan di tingkat pemerintah pusat antar kementerian terkait: Dikategorikannya panas bumi sebagai kegiatan pertambangan dengan menggunakan kawasan hutan menyebabkan koordinasi antara Kementerian ESDM melalui Direktorat Jenderal Energi Baru Terbarukan dan Konservasi Energi sulit memperoleh izin penggunaan kawasan hutan dari Kementerian Kehutanan (Kemenhut-kini Kemenhut LH) melalui Direktorat Planologi Kehutanan untuk kawasan hutan produksi dan kawasan hutan lindung sedangkan kawasan hutan konservasi melalui Direktorat Jenderal Perlindungan Hutan dan Konservasi Alam serta Kementerian Lingkungan Hidup (KLH-kini Kemenhut $\mathrm{LH}$ ) terkait izin lingkungan dalam merealisasikan proyek panas bumi;

b) Koordinasi kewenangan antara pemerintah pusat, pemerintah provinsi, dengan pemerintah kabupaten/kota terkait perizinan pemanfaatan tidak langsung dilakukan secara berjenjang sedangkan sumber daya manusia di daerah sering kali tidak memahami mekanisme perizinan wilayah kerja pertambangan panas bumi dan pelelangan;

c) Koordinasi antara pelaku usaha dengan PT Perusahaan Listrik Negara: Terbukanya peluang pelaku usaha (non PLN) berkontribusi pada penyediaan listrik di Indonesia merupakan suatu solusi yang mampu mengatasi masalah dari terlalu cepatnya kenaikan tingkat kebutuhan listrik. Namun, jual beli listrik dan uap dari energi panas bumi belum menemui titik temu antara PLN dengan pelaku usaha.

d) Koordinasi pemerintah pusat, pemerintah provinsi, dengan pemerintah kabupaten/kota terkait isu sosial: Peningkatan dan pemahaman masyarakat melalui sosialisasi, baik secara luas maupun kepada masyarakat di sekitar wilayah pengusahan panas bumi yang tidak menimbulkan dampak lingkungan, sangat dibutuhkan. Selain itu, keterlibatan masyarakat terhadap proyek pembangkit listrik tenaga panas bumi dalam bentuk lapangan kerja juga merupakan kewajiban pengembang. 
Sementara itu, berkenaan dengan perizinan penggunaan kawasan hutan telah diatasi dengan adanya Nota Kesepahaman sebagaimana telah dipaparkan sebelumnya. Apabila merujuk Tabel 1 di atas, maka terdapat beberapa proyek pembangkit tenaga listrik panas bumi (PLTP) seperti: (1) PLTP Karaha Bodas; (2) PLTP Gunung Tampomas; (3) PLTP Tangkuban Perahu; dan (4) PLTP Cisolok Sukarame. Terbitnya Nota Kesepahaman ini bertujuan untuk mempercepat proses perizinan bertahap yang perlu dikeluarkan oleh Kementerian ESDM, Kemenhut LH, maupun pemerintah daerah provinsi dan pemerintah kabupaten/kota pada wilayah administrasi pemerintahan daerah pada pengusahaan panas bumi di kawasan hutan produksi dan hutan lindung serta mempersiapkan langkah-langkah agar kegiatan pemanfaatan panas bumi dapat dilakukan di kawasan hutan konservasi dengan tetap mempertimbangkan prinsip-prinsip konsevasi.

Walaupun demikian, Nota Kesepahaman tersebut dalam praktik hukum tidak dapat dianggap sebagai perjanjian berdasarkan Pasal 1320 dan Pasal 1338 Kitab Undang-Undang Hukum Perdata (KUHPerdata). Dalam praktik, hal ini memberi kesan memperluas penguasaan jenis usaha panas bumi yang dikategorikan sebagai pertambangan yang dapat dilakukan pada lahan kawasan hutan produksi, kawasan hutan lindung, dan kawasan hutan konservasi. Hal ini bertentangan dengan UU Kehutanan sebagaimana telah disinggung sebelumnya, serta selaras dengan Pasal 33 UU Konservasi SDA yang mengatur:

(1) Setiap orang dilarang melakukan kegiatan yang dapat mengakibatkan perubahan terhadap keutuhan zona inti taman nasional;

(2) Perubahan terhadap keutuhan zona inti taman nasional sebagaimana dimaksud dalam ayat (1) meliputi mengurangi, menghilangkan fungsi dan luas zona inti taman nasional, serta menambah jenis tumbuhan dan satwa lain yang tidak asli; dan

(3) Setiap orang dilarang melakukan kegiatan yang tidak sesuai dengan fungsi zona pemanfaatan dan zona lain dari taman nasional, taman hutan raya, dan taman wisata alam.

Selanjutnya, Nota Kesepahaman juga bertentangan dengan Pasal 35 ayat (1) PP 26/2011 yang mengatur bahwa taman nasional dapat dimanfaatkan untuk kegiatan:

a. penelitian dan pengembangan ilmu pengetahuan;

b. pendidikan dan peningkatan kesadartahuan konservasi alam;

c. penyimpanan dan/atau penyerapan karbon, pemanfaatan air serta energi air, panas, dan angin serta wisata alam;

d. pemanfaatan tumbuhan dan satwa liar;

e. pemanfaatan sumber plasma nutfah untuk penunjang budidaya; dan

f. pemanfaatan tradisional oleh masyarakat setempat. 
Mengenai frasa kata 'panas' dalam penjelasan Pasal 35 ayat (1) huruf c disebutkan bahwa pemanfaatan energi yang dapat diperbaharui dihasilkan dari jasa panas yang pemanfaatannya tidak dilakukan melalui penambangan merujuk pada pemanfaatan energi panas matahari untuk pembangkit listrik (solar cell). Selain itu, berdasarkan Pasal 2 ayat (1) Peraturan Presiden Nomor 28 Tahun 2011 tentang Penggunaan Kawasan Hutan Lindung dinyatakan bahwa "di dalam kawasan hutan lindung dapat dilakukan kegiatan penambangan dengan metode penambangan bawah tanah". Pasal 5 ayat (1) huruf b Peraturan Menteri Kehutanan Nomor P.16/MENHUT-II/2014 tentang Pedoman Pinjam Pakai Kawasan juga turut mengatur bahwa penambangan dengan pola pertambangan bawah tanah yang dilakukan dalam kawasan hutan lindung dilarang mengakibatkan:

1. turunnya permukaan tanah;

2. berubahnya fungsi pokok kawasan hutan secara permanen; dan

3. terjadinya kerusakan akuiver air tanah.

Beberapa pemaparan materi muatan peraturan perundang-undangan di atas jelas membatasi pengusahaan panas bumi di kawasan hutan konservasi dan berdasarkan Pasal 19 UU Kehutanan telah diatur bahwa:

"Perubahan peruntukan dan fungsi kawasan hutan dapat dilakukan dengan persyaratan ketat. Syaratnya yaitu untuk cakupan luas tertentu, bernilai strategis, dan berdampak penting. Ketiganya harus dilakukan dengan persetujuan Dewan Perwakilan Rakyat."

Dalam konteks pengawasan sebagaimana diatur dalam ketentuan ini, belum berjalan optimal dengan merujuk pada beberapa wilayah hutan ditetapkan oleh pemerintah dan pemerintah daerah. Di samping itu, penyelesaian 12 (dua belas) proyek panas bumi yang ada dalam kondisi mangkrak dan sebagian besar berlokasi di Pulau Jawa, salah satunya terletak di Gunung Ciremai Jawa Barat.

Atas kendala tersebut, Kementerian Dalam Negeri (Kemendagri) mempersiapkan rancangan perubahan UU Pemda 2004 diiringi rancangan perubahan UU Panas Bumi 2003 oleh Kementerian ESDM di tahun 2012. Kemudian UndangUndang Nomor 21 Tahun 2014 tentang Panas Bumi (UU Panas Bumi 2014) diundangkan dan disahkan lebih awal pada 17 September 2014, sedangkan Undang-Undang Nomor 23 Tahun 2014 tentang Pemerintahan Daerah (UU Pemda 2014) pada 30 September 2014. Kedua peraturan peraturan perundang-undangan ini menunjukan perubahan terkait pembagian urusan konkuren dan kewenangan yang terdiri atas:

(1) Urusan pemerintahan wajib yang berkaitan dengan pelayanan dasar, salah satunya meliputi penataan ruang. Pemerintah provinsi tidak memiliki kewenangan perizinan tetapi mengkoordinasikan usulan tata ruang dari pemerintah kabupaten/kota; dan 
(2) Urusan pemerintahan pilihan meliputi bidang kehutanan sub urusan konservasi sumber daya alam hayati dan ekosistemnya, serta energi dan sumber daya mineral sub energi baru dibagi antara pemerintah pusat dan daerah provinsi.

Terkait penjabaran urusan pemerintahan di atas, dijelaskan dalam bagian lampiran UU Pemda 2014 sebagai berikut:

Tabel 2: Pembagian Urusan Pemerintahan Pilihan Lintas Sektor Kehutanan Berdasarkan UU Pemda 2014

\begin{tabular}{|l|c|c|}
\hline \multicolumn{3}{|c|}{ Lampiran BB Pembagian Urusan Pemerintahan Bidang Kehutanan } \\
\hline \multicolumn{2}{|c|}{ Angka 3 Sub Urusan Konservasi Sumber Daya Alam Hayati dan Ekosistemnya } \\
\hline \multicolumn{1}{|c|}{$\begin{array}{c}\text { Pemerintah Pusat } \\
\text { berwenang }\end{array}$} & $\begin{array}{c}\text { Pemerintah Provinsi } \\
\text { berwenang }\end{array}$ & $\begin{array}{c}\text { Pemerintah Kabupaten/Kota } \\
\text { berwenang }\end{array}$ \\
\hline $\begin{array}{l}\text { Mengelola kawasan } \\
\text { suaka alam dan kawasan } \\
\text { pelestarian alam }\end{array}$ & $\begin{array}{l}\text { Mengelola kawasan } \\
\text { bernilai ekosistem penting } \\
\text { dan penyangga kawasan } \\
\text { suaka alam dan kawasan } \\
\text { pelestarian alam }\end{array}$ & $\begin{array}{l}\text { Mengelola taman hutan } \\
\text { raya }\end{array}$ \\
\hline
\end{tabular}

Tabel 3: Pembagian Urusan Pemerintahan Pilihan Lintas Sektor Sumber Daya Energi dan Mineral Berdasarkan UU Pemda 2014

\begin{tabular}{|c|c|c|}
\hline \multicolumn{3}{|c|}{ Lampiran CC Pembagian Urusan Pemerintahan Bidang Energi dan Sumber Daya Mineral } \\
\hline \multicolumn{3}{|c|}{ Angka 4 Sub Energi Baru Terbarukan } \\
\hline $\begin{array}{c}\text { Pemerintah Pusat } \\
\text { berwenang }\end{array}$ & $\begin{array}{c}\begin{array}{c}\text { Pemerintah Provinsi } \\
\text { berwenang }\end{array} \\
\end{array}$ & $\begin{array}{c}\text { Pemerintah Kabupaten/Kota } \\
\text { berwenang }\end{array}$ \\
\hline $\begin{array}{l}\text { - } \text { Menetapkan Wilayah } \\
\text { Kerja Panas Bumi (WKP). } \\
\text { Melakukan pelelangan } \\
\text { WKP. } \\
\text { - Menerbitkan izin panas } \\
\text { bumi untuk } \\
\text { pemanfaatan tidak } \\
\text { langsung untuk } \\
\text { pembangkit tenaga } \\
\text { listrik. }\end{array}$ & $\begin{array}{l}\text { Menerbitkan izin } \\
\text { pemanfaatan langsung } \\
\text { panas bumi untuk } \\
\text { keperluan non listrik lintas } \\
\text { daerah kabupaten/kota } \\
\text { dalam } 1 \text { (satu) daerah } \\
\text { provinsi. }\end{array}$ & $\begin{array}{l}\text { - Menerbitkan izin } \\
\text { pemanfaatan langsung } \\
\text { panas bumi dalam daerah } \\
\text { manfaatan WKP panas } \\
\text { bumi secara langsung } \\
\text { untuk keperluan non } \\
\text { listrik. }\end{array}$ \\
\hline \multicolumn{3}{|c|}{ Angka 5 Ketenagalistrikan } \\
\hline $\begin{array}{l}\text { Pemerintah Pusat } \\
\text { berwenang }\end{array}$ & $\begin{array}{l}\text { Pemerintah Provinsi } \\
\text { berwenang }\end{array}$ & $\begin{array}{l}\text { Pemerintah Kabupaten/Kota } \\
\text { berwenang }\end{array}$ \\
\hline $\begin{array}{l}\text { - } \\
\text { usahetapkan wilayah } \\
\text { listik dan izin jual beli } \\
\text { tenaga listrik lintas } \\
\text { negara. } \\
\text { Menerbitkan izin usaha } \\
\text { jasa penunjang tenaga } \\
\text { listrik yang dilakukan } \\
\text { oleh badan usaha milik } \\
\text { negara atau penanaman } \\
\text { modal asing/mayoritas }\end{array}$ & $\begin{array}{l}\text { Menerbitkan izin usaha } \\
\text { penyediaan tenaga listrik } \\
\text { non badan usaha milik } \\
\text { negara dan penjualan } \\
\text { tenaga listrik serta } \\
\text { penyewaan jaringan } \\
\text { kepada penyedia tenaga } \\
\text { listrik dalam daerah } \\
\text { provinsi. } \\
\text { Menerbitkan izin operasi } \\
\text { yang fasilitas instalasinya } \\
\text { dalam daerah provinsi. }\end{array}$ & - \\
\hline
\end{tabular}




\begin{tabular}{|c|c|c|}
\hline \multicolumn{3}{|c|}{ Angka 5 Ketenagalistrikan } \\
\hline $\begin{array}{l}\text { Pemerintah Pusat } \\
\text { berwenang }\end{array}$ & $\begin{array}{l}\text { Pemerintah Provinsi } \\
\text { berwenang }\end{array}$ & $\begin{array}{l}\text { Pemerintah Kabupaten/Kota } \\
\text { berwenang }\end{array}$ \\
\hline $\begin{array}{l}\text { sahamnya dimiliki oleh } \\
\text { penanaman modal asing. }\end{array}$ & $\begin{array}{l}\text { Menetapkan tarif tenaga } \\
\text { listrik untuk konsumen } \\
\text { dan Penerbitan izin usaha } \\
\text { jasa penunjang listik bagi } \\
\text { badan usaha dalam } \\
\text { negeri/mayoritas dimiliki } \\
\text { penanaman modal dalam } \\
\text { negeri. }\end{array}$ & \\
\hline
\end{tabular}

Mengenai lampiran di atas, Pasal 15 ayat (1) UU Pemda 2014 menjelaskan sebagai berikut: "Pembagian urusan pemerintahan konkuren antara Pemerintah Pusat dan Daerah Provinsi serta Daerah Kabupaten/Kota tercantum dalam Lampiran yang merupakan bagian yang tidak terpisahkan dari Undang-Undang ini." Dari ketentuan ini, maka Peraturan Pemerintah Nomor 38 Tahun 2007 tentang Pembagian Urusan Pemerintah Provinsi Kabupaten Kota secara mutatis mutandis tidak berlaku yang selanjutnya dalam hal materi muatan kewenangan diatur masing-masing sesuai dengan peraturan perundang-undangan (UU Pemda 2014 dan UU Panas Bumi 2014).

Namun demikian, dalam kerangka pemanfaatan tidak langsung panas bumi untuk keperluan penyediaan tenaga listrik menimbulkan kerancuan. Di satu sisi, UU Ketenagalistrikan berkarakter otonomi daerah dan tugas pembantuan, sedangkan di sisi lain UU Pemda 2014 dan UU Panas Bumi 2014 berkarakter sentralisasi sebagaimana digambarkan dalam Tabel 3. Pemerintah kabupaten/kota tidak mempunyai kewenangan, namun dalam hal tanggung jawab UU Ketenagalistrikan terdapat penambahan prinsip pemerintahan daerah yakni kepentingan strategis sehingga pemerintah kabupaten/kota masih memiliki kewenangan.

Hal ini dapat menimbulkan perselisihan kewenangan antara pemerintah kabupaten/kota dengan kementerian terkait dalam menjalankan kewenangannya sehingga pembagian urusan pemerintah belum sesuai dengan Pasal 18 UUD 1945. Desain konstitusi terkait distribusi urusan pemerintahan ini telah secara definitif dituangkan dalam Pasal 18 ayat (2) UUD 1945 yang menyatakan, "Pemerintahan daerah provinsi, daerah kabupaten, dan kota mengatur dan mengurus sendiri urusan pemerintahan menurut asas otonomi dan tugas pembantuan."15 Pengaturan tersebut memberikan kejelasan bahwa pelaksana urusan pemerintahan adalah provinsi dan kabupaten/kota, selain tentu saja Kementerian Negara. ${ }^{16}$

15 Dian Agung Wicaksono, "Transformasi Pengaturan Distribusi Urusan Pemerintahan dari Pemerintah Pusat kepada Pemerintahan Daerah", Padjadjaran Jurnal Ilmu Hukum, Vol. 2, No. 3, 2015, hlm. 466.

16 Ibid. 


\section{Perselisihan Kewenangan}

Rencana Kementerian ESDM untuk membangun PLTP pasca diterbitkannya UU Pemda 2014 dan UU Panas Bumi 2014 mendapatkan penolakan baik secara teknis maupun dari pertimbangan aspek sosial, dari kepala pemerintah daerah dan masyarakat yang terjadi di sebagian wilayah di Pulau Jawa seperti Kuningan, Jawa Barat, Karanganyar, Jawa Tengah, Jawa Timur dan Bedugul, Tabanan, Bali. Meskipun begitu, kondisi penolakan yang terjadi atas pertimbangan ekologi dan sosial tetap tidak menghentikan Kementerian ESDM yang melanjutkan kembali proyek.

Terkait dengan hal tersebut, Pemerintah Provinsi Jawa Timur mengajukan permohonan pengujian undang-undang kepada Mahkamah Konstitusi dengan Nomor 11/PUU/-XIV Perihal Pengujian Undang-Undang Nomor 21 Tahun 2014 tentang Panas Bumi dan Undang-Undang Nomor 23 Tahun 2014 tentang Pemerintahan Daerah, dan kita masih menanti putusannya. Merujuk risalah sidang pada 11 Mei 2016 diketahui alasan pemerintah pusat tidak melibatkan pemerintah daerah untuk pemanfaatan tidak langsung dalam penyediaan tenaga listrik dikarenakan pengusahaan panas bumi untuk pemanfaatan tidak langsung diserahkan kepada pemerintah pusat karena lebih berdampak nasional atau meluas secara ekonomi dan digunakan secara nasional. Maka dalam kaitannya dengan alasan tersebut pemerintah pusat lebih menekankan prinsip eksternalitas sedangkan prinsip akuntabilitas dan efisiensi justru dikesampingkan.

\section{Penutup}

Persoalan khas dalam hubungan pemerintah antara pusat dan daerah di Indonesia dari masa ke masa selalu sama, yakni pembagian tugas dan pembagian sumber daya ekonomi yang diwarnai tarik-menarik kepentingan. Sentralisasi dan desentralisasi adalah pasang surut dalam pengelolaan negara sejak Indonesia merdeka hingga kini. Koordinasi pembangunan PLTP antar level pemerintah disebut sebagai obat mengatasi persoalan, namun dalam praktik hal ini tidak mudah dilaksanakan. Hal ini bersinggungan dengan perubahan Undang-Undang Pemerintahan Daerah dan Undang-Undang Panas Bumi, namun pembagian kewenangan tersebut belum sesuai dengan Pasal 18 UUD 1945 yang menimbulkan perselisihan kewenangan sehingga selanjutnya diselesaikan melalui Mahkamah Konstitusi.

\section{Daftar Pustaka}

\section{Buku}

Herman Hidayat (et.al.), Politik Ekologi: Pengelolaan Taman Nasional Era Otda, Lembaga Ilmu Pengetahuan Indonesia dan Yayasan Pustaka Obor Indonesia, Jakarta, 2011.

Tuti Ermawati dan Siwage Dharma Negara, Pengembangan Industri Energi 
Alternatif: Studi Kasus Energi Panas Bumi di Indonesia, Lembaga IImu Pengetahuan Indonesia Press, Jakarta, 2014.

\section{Dokumen Lain}

A. Hamid S. Attamimi, "Peranan Keputusan Presiden Republik Indonesia Dalam Penyelenggaraan Pemerintahan Negara: Suatu Studi Analisis Mengenai Keputusan Presiden Yang Berfungsi Pengaturan Dalam Kurun Waktu Pelita I Pelita VI", Disertasi, Fakultas Pasca Sarjana Universitas Indonesia, Jakarta, 1990. Agus Sugiyono, (et.al.) (eds), “Outlook Energi Indonesia 2016: Pengembangan Energi Untuk Mendukung Industri Hijau", Pusat Teknologi Sumber Daya Energi dan Industri Kimia dan Badan Pengkajian dan Penerapan Teknologi, Jakarta, 2016.

Dian Agung Wicaksono, "Transformasi Pengaturan Distribusi Urusan Pemerintahan dari Pemerintah Pusat Kepada Pemerintahan Daerah", Padjadjaran Jurnal IImu Hukum, Vol. 2, No. 3, 2015.

Direktoral Jenderal Ketenagalistrikan Kementerian Energi dan Sumber Daya Mineral, "Pemerintah Dorong Swasta Kembangkan Listrik Perdesaan", http://www.djk.esdm.go.id/index.php/detail-berita?ide=4210, diakses 26 Maret 2015.

Direktorat Sumber Daya Energi, Mineral dan Pertambangan, "Keselarasan Kebijakan Energi Nasional Dengan Rencana Umum Energi Nasional dan Rencana Umum Energi Daerah", Policy Paper, Badan Perencanaan Pembangunan Nasional, 2012.

Hermawan, "Lestarikan Hutan dan Lingkungan",

http://www.dishut.jabarprov.go.id/index.php?mod=detilSorotan\&idMenuKiri =345\&idSorotan=93, diakses 9 Desember 2016.

Hukum Online, "Membedah Logika Hukum Peraturan Pemerintah Kebijakan Energi", http://www.hukumonline.com/berita/baca/lt5301fa9d4242f/ membedah-logika-hukum-pp-kebijakan-energi, diakses 17 Februari 2014.

Kementerian Energi dan Sumber Daya Mineral, "Rencana Strategis Kementerian Energi dan Sumber Daya Mineral Tahun 2010-2014", 2010.

"Tanpa Pertumbuhan Pembangkit,

2018 Pulau Jawa Krisis Listrik", http://www2.esdm.go.id/berita/

39-listrik/6745-tanpa-pertumbuhan-pembangkit-2018-pulau-jawa-krisislistrik.html, diakses 26 Maret 2015.

\section{Dokumen Hukum}

Putusan Mahkamah Konstitusi No. 31/PUU-IV/2006, putusan diucapkan dalam sidang Pleno Mahkamah Konstitusi yang terbuka untuk umum pada hari Selasa, 25 Juli 2006. 